\title{
Charles Sheeler's Paragone: Literary Influence and the Shaping of a Hierarchy
}

\author{
Heather L. Stark \\ Marshall University, Huntington, USA
}

\begin{abstract}
This study is concerned with the literary and aesthetic influences that led to Charles Sheeler's formation of a paragone in his early 20th century work. This painter, photographer, printmaker, and experimental filmmaker had very specific ideas concerning the hierarchy of the visual arts. While he is known for embracing a wide range of media and materials, by 1919 his aesthetic thought reveals a desire to elevate the painting over all other media. This formation of a visual paragone was initially influenced by his involvement in the interdisciplinary circles which surrounded both Alfred Stieglitz and Walter and Louise Arensberg in New York City. In particular, his lifelong friendship with the poet and writer William Carlos Williams would shape his aesthetic thought leading to his elevation of painting over all other media. Sheeler's paragone would begin to form during his stays at the rural Doylestown House in Bucks County, Pennsylvania. This rural home, which he first rented with fellow painter Morton Schamberg in 1916, would become an artistic refuge for both artists. While commercial photography was beginning to take up more if his time in Philadelphia, it was the retreats to the Doylestown house that enabled Sheeler to continue experiments in painting and begin to think of the photograph as something other than a document of architectural work. At this early stage in his artistic career, Sheeler was beginning to form his own hierarchy and contribute to the continuing argument of painting versus photography.
\end{abstract}

Keywords: aesthetics, early 20th century American art, interdisciplinarity, localism

\section{Introduction}

By the late 1920s American artist Charles Sheeler had become famous for his work as a commercial photographer, notably for his photographs of the Ford Motor Company's River Rouge Plant near Detroit, Michigan. However, this painter, photographer, printmaker, and experimental filmmaker had very specific ideas concerning the hierarchy of the visual arts. While he is known for embracing a wide range of media and materials, by 1919 his aesthetic thought reveals a desire to elevate the painting over all other media. This formation of a visual paragone was initially influenced by his involvement in the interdisciplinary circles which surrounded Alfred Stieglitz and Walter and Louise Arensberg in New York City. In addition, his lifelong friendship with the poet and writer William Carlos Williams would help shape his aesthetic thought leading to his elevation of painting over all other media. Williams and Sheeler, who met in 1919, would carry on a conversation about their creative processes throughout their lives. It seems clear within Sheeler's unpublished autobiography, artist statements, correspondences, and other writing that he truly prized this form above all others. This understanding and creation of a personal paragone was forged through this conversation between artist and writer.

Heather L. Stark, Assistant Professor of Art History, Ph.D. in Interdisciplinary Arts, Marshall University. 


\section{The Search for an American Aesthetic}

While Williams elevated the poem above prose, Sheeler prized the painting, even the drawing, above the photograph. They held a shared understanding of the expressive qualities afforded by the sense of accumulated experience embodied within these respective art forms. Williams would refer to this representation of the underlying facets of the immediate environment, in written and visual form, as an expression of the "local". Sheeler's development as a painter, in response to Williams' writing and calls for the creation of a truly American aesthetic through the local, led him to this hierarchy. Before the two ever met, there was a strong confluence between their aesthetic aims, and after their introduction this shared methodology developed into a series of influences passed back and forth between the two artists. ${ }^{1}$ From an art historical perspective very few attempts have been made toward a more thorough understanding of this interdisciplinary relationship. ${ }^{2}$

Sheeler's conception of the artistic process was also greatly impacted by his early years with classmate and friend Morton Schamberg in their rented eighteenth-century studio in Doylestown, Pennsylvania. The cultural historian Constance Rourke, who would become Sheeler's first biographer in 1938, made some important observations about this period in both Schamberg's and Sheeler's careers starting around 1910. She elaborates upon Sheeler's desire to keep his art within its own sacred realm, and to separate it from his "industrial arts" training. She notes that this was the period during which Sheeler began to see photography as a "means to an end", as a way to supplement his income, while enabling him to continue on with his painting:

Up to this time Sheeler had taken only casual snapshots with a Kodak, but he now purchased a large camera, studied its uses, and found a field for himself in Philadelphia photographing newly finished houses for their architects, who wanted the prints mainly as records. The houses were often bad hybridizations, but the effort to transcribe their masses with honesty by means of the camera meant that earning a living was not after all wholly divorced from pure esthetics. This work ran parallel to his new preoccupation with structural form in painting. (Rourke, 1938, p. 29)

While photography was slowly beginning to take up more of his time in Philadelphia, it was the retreats to the house in Doylestown that enabled Sheeler to continue his painting and to begin to think of the photograph as something other than a document of architectural work. It is also apparent that even at this early stage in his artistic career Sheeler had formed his own paragone within the visual arts; painting had already trumped the photograph.

It was during Sheeler's formative years of painting, the period spanning 1915 to 1922, that he was introduced to the prevailing desire among American artists to establish an aesthetic of their own, one freed from their European counterparts. It is also during this period that Sheeler made friendships, both personal and professional, that forever altered his ideas towards his own process. Sheeler began to study the history of

\footnotetext{
${ }^{1}$ On Williams and the visual arts see Terrence Diggory, Williams Carlos Williams and the Ethics of Painting (Princeton: Princeton University Press, 1991); Bram Dijkstra, ed. A Recognizable Image: William Carlos Williams on Art and Artists (New York: New Directions, 1978); Bram Dijkstra, Cubism, Stieglitz, and the Early Poetry of Williams Carlos Williams (Princeton: Princeton University Press, 1978); Peter Halter, The Revolution in the Visual Arts and the Poetry of Williams Carlos Williams (Cambridge: Cambridge University Press, 1994); Williams Marling, William Carlos Williams and the Painters, 1909-1923 (Athens: Ohio University Press, 1982); Henry M. Sayre, The Visual Text of Williams Carlos Williams (Urbana: University of Illinois Press, 1983); Peter Schmidt, Williams Carlos Williams, the Arts, and Literary Tradition (Baton Rouge: Louisiana State University Press, 1988); and Dickran Tashjian, William Carlos Williams and the American Scene, 1920-1940 (New York: Whitney Museum of American Art, 1978).

${ }^{2}$ Rick Stewart provides the sole example of a scholarly work that delves deeper into the questions of influence and confluence within their works. Rick Stewart, "Charles Sheeler, William Carlos Williams, and Precisionism: A Redefinition” Arts Magazine vol. 58: 3 (November 1983).
} 
American art, and, through his time at the Doylestown house, became a collector of early American folk art. Many discussions concerning the state of the arts in America began to take place in earnest, primarily through early arts journals, including The Dial, Seven Arts, Broom, The Soil, Camera Work, and Williams' own Contact. These journals afforded contemporary writers, critics, and artists the opportunity to express their views on the state of American art, as well as to provide an outlet to share their work with peers and the public. There was a strong desire to create an aesthetic in painting and poetry that would be seen as truly American, an aesthetic that could only be achieved, according to Williams, through a local expression. This expressive desire would help lead Sheeler to the determination that the photograph was simply a "single image", while the painting was a "composite image". ${ }^{3}$

\section{The Expression of the Local}

When Sheeler first met Williams, he had already been reading the poet's work published in Broom, and likely other places as well. During this meeting, Sheeler reportedly exclaimed "[h]ere is the man I've been looking for all my life!” (Rourke, 1938, p. 49). ${ }^{4}$ It is obvious that both artists were aware of one another prior to their formal introduction. Sheeler had been particularly drawn to Williams' prose work. The artist had been reading portions of the yet to be completed In the American Grain within the pages of Broom. Sheeler and Williams both strove to work through the particularities of their immediate environment to convey a sense of place, or the local, in American life. Along with the second circle of artists surrounding Alfred Stieglitz, they looked to their own soil in the search for a new direction within modern American painting and writing. In 1920, Williams and Robert McAlmon established their literary journal Contact, which found its rallying call in the voice of the philosopher John Dewey. Contact was one of a number of small journals that popped up during the late teens and early twenties in New York. That this journal was inaugurated one year after Williams and Sheeler's first meeting seems quite fortuitous. In effect, the journal set forth the ideas that the artist and writer would cultivate within their respective work for the entirety of their careers.

While Williams put forth the call for the representation of the "local" in visual and literary art, Sheeler was busy developing his style as both a commercial photographer and a painter. Sheeler's work made major strides from the Armory Show of 1913 until his 1920 foray into experimental filmmaking with the photographer Paul Strand. Their collaboration on Manhatta (1920), often called the first avant-garde film in the history of American cinema, forever affected the development of Sheeler as a painter and the formation of his personal paragone (Horak, 1995, p. 267). This film, based on a day in the life of Manhattan, marked a decisive moment for Sheeler in terms of his approach toward form, a straight-photographic style with extreme view points. This experience appears to have provided Sheeler with a stronger understanding of Cubism and its relationship to film. With this film Sheeler moved away from his early teachers, most notably William Merritt Chase, and their aesthetic influences to his own understanding of what a painting should be. It was only after this experience that Sheeler began to realize the priority painting held above other media. This collaboration marks an oft-neglected crossroads in Sheeler's conception of the painting process. ${ }^{5}$

\footnotetext{
3 See Charles Sheeler Papers, “Autobiography” (Washintgton D.C.: Smithsonian Institution Archives of American Art), p. 70.

${ }^{4}$ Rourke continues writing that Williams was already familiar with Sheeler's work, and noticed a bond between their expressive aims.

5 The meeting occurred in 1917 at Stieglitz's “291”, while Sheeler was visiting New York from Philadelphia; they formed a closer friendship after Sheeler moved to New York in 1919. Jan-Christopher Horak, p. 268.
} 


\section{Manhatta and Sheeler's Hierarchy of Media}

The first painting to result from Sheeler's work on Manhatta, Church Street El (1920), serves as a blueprint for what is to come within his imagery. With this composition, taken from a Manhatta still, Sheeler breaks down the photograph into its underlying, internal structure. He begins to look more closely for those ideal forms below the surface of reality. In his own words, Sheeler describes this as a period during which he was just beginning to understand what he wanted to express about his subject matter through the manipulation of form. Sheeler talks about this stage in his development as a painter, after moving from Philadelphia to New York City in 1919, and, subsequently, meeting Williams:

In New York the abstract period, which brought the Philadelphia chapter to a close, was followed by a gradual return to the use of natural forms, but with the difference of interest in a secure underlying structure of the basis of design, an equivalent for a steel frame which would support the bricks and mortar. ${ }^{6}$

Sheeler goes on to discuss the influence of his days in Europe as a student, when he admired the work of Holbein and Van Eyck, particularly their ability to conceal the process of painting. Sheeler's desire to conceal the process of painting became an important aspect of his elevation of this form above that of photography. This coupled with the influence of Williams led him to a sharp distinction between the two processes. He elaborates upon this conception of the painting as a "composite image" and the photograph as a "single image" within his unpublished autobiography (Sheeler, 1939, p. 11):

This has to do with the mechanics of painting. Because of the length of time the eye of the artist is looking, while its recording is taking place, it is inevitable that it will be seeing not one, but a succession of images, with the resulting evidence in the course of progression toward the completed work. This likewise has to do with esthetics. ${ }^{7}$

It seems that even by 1920 Sheeler knew that painting would be the medium through which he could best express multiple layers of meaning.

Sheeler's statement concerning his aesthetics also reveals an understanding of John Dewey's aesthetic theory via Williams. When Williams grabbed hold of Dewey's article “Americanism and Localism”, published in a 1920 issue of The Dial, he found a philosophical basis for his poetic ideology of the local, as well as a rallying call for his new journal Contact. Williams' first issue of Contact was in the form of a sort of manifesto of the local, as well as a call for artists and writers interested in this sort of expressive aim. This December 1920 issue, co-edited by Robert McAlmon, would have been released just a month prior to the New York premiere of Manhatta. Williams and McAlmon called for "native work in verse, fiction, criticism" that was interested in asserting a sense of place, "insisting on that which we have not found insisted upon before, the essential contact between words and the locality that breeds them, in this case America” (Williams \& McAlmon, 1920, p. 10). Then in January 1921, as Manhatta was appearing at the Rialto, Williams and McAlmon published their first full volume of Contact. Within its pages Williams elaborates further on his conception of the local, and begins to assimilate Dewey’s ideas found in "Americanism and Localism" into his own ideology. In "Americanism and Localism", Dewey sets forth an idea that would become essential to Williams', and, in turn, Sheeler's aesthetic:

\footnotetext{
${ }^{6}$ See Charles Sheeler Papers, “Autobiography”, p. 70.

7 See Charles Sheeler Papers, “Autobiography”, p. 77.
} 
We are discovering that the locality is the only universal. Even the suns and stars have their own times as well as their own places. The truth is first discovered in abstract form, or as an idea. Then as Mr. Oppenheim points out in the February Dial, its discovery creates a new poetry- at least so I venture to paraphrase him. When the discovery sinks a little deeper, the novelist and dramatist will discover the localities of America as they are, and no one will need to worry about the future of American Art. We have been too anxious to get away from home. Naturally that took us to Europe even though we fancied we were going around America. When we explore our neighborhood, its forces and not just its characters and colour, we shall find what we sought. (Dewey, 1920, pp. 687-688)

Williams had always been interested in the visual arts, and even entertained thoughts of becoming a painter himself. The Arensbergs' studio, during the height of its popularity, contained works of modern art by Brancusi, Matisse, Duchamp, Sheeler, and Schamberg, and was viewed by its inhabitants as a space for the “sacred” act of "artistic reflection” (Marling, 1982, pp. 6-7):

“I almost became a painter," wrote William Carlos Williams in 1954, "and had it not been that it was easier to transport a manuscript than a wet canvas, the balance might have been tilted the other way.” This statement contains some hyperbole and a good deal of truth. In 1907 Williams was poised between the two arts, but his momentum had always been toward poetry. He continued his painting until he was in his early thirties, however, and he was serious about it. Raised in the traditions and ambience of painting, he sought out and made friends with painters all his life. (Marling, 1982, p. 1)

This lifelong interest in the world of the visual arts (his mother was trained in Europe as a painter) was manifesting itself within his poetry, culminating in his 1917 Al Que Quiere! Bram Djikstra isolates the poems "Dawn”, “Spring Strains”, “Winter Quiet”, and “A Portrait in Greys” as examples of Williams' successful dissolution of narrative sequence. This compositional change would move his conception of poetry from the temporal to the spatial, further aligning it with the visual arts, painting in particular. Djikstra calls "Spring Strains" an "elaborate attempt at painting a Cubist picture in words" (Dijkstra, 1978, pp. 52-53).

From 1923 to 1929, Sheeler experienced a lull in his painting production. Nevertheless, it was during this period that he realized and articulated an understanding of the process of painting that remained with him throughout his life. This period culminated in what Sheeler has often called his most important painting-The Upper Deck (1929). Unlike his previous paintings, Sheeler took a painstaking amount of time planning out this work, not only analyzing the photographic source, but also working from an accumulated bank of memory and experience. Karen Lucic remarks that as of the late 1920s and early 1930s, when Sheeler had left photography to put all his efforts into painting, it was not unusual for him to spend seven to eight hours a day at his easel, while sometimes taking up to nine months to finish an average sized work (Lucic, 1997, p. 96). Sheeler comments upon this time in his painting within his own writing. His unpublished autobiography, artist statements, correspondences, and other writing attest to his own view that his process was coming to a turning point.

\section{The Painter and the Poet}

It is uncanny how Sheeler's trajectory as a painter parallels that of Williams' poetic form. Their stylistic development from 1920 to 1925 moved through the same experimental route, from Dadaism to Cubism to Objectivism and, finally, to Precisionism/Realism. Williams emphasizes this shared sense of form and expression of the local in an introduction to a 1939 exhibit of Sheeler's work at the Museum of Modern Art:

To discover and separate things from the amorphous, the conglomerate normality with which they are surrounded and of which before the act of "creation" each is a part, calls for an eye to draw out that detail which is in itself the thing, to clinch our insight, that is, our understanding of it. It is this eye for the thing that most distinguished Charles Sheeler and 
along with it to know that every hair on everybody, now or then, in its minute distinctiveness is the same hair, on every body anywhere, at any time, changes as it may be to feather, quill or scale. The local is the universal. It was a banana to Cézanne. (Williams, 1939b, p. 8)

To Sheeler, for the time being, the local became the Doylestown house. The house, for Sheeler, is a place constructed in the American grain, and it, therefore, became his local subject, as explained by Williams. The house holds the essence of both historic America and Sheeler's contemporary life. It is a vehicle of place through which Sheeler could achieve self-expression. Sheeler's distinction between the processes of photography and painting is also important in understanding his painted and drawn representations of the house. The painting can convey a multitude of meanings through form, while the photograph enables the artist to capture the fleeting moment. Sheeler writes that photography was man's vision of nature "from the eyes outward", while painting moves "from the eyes inward". ${ }^{8}$ He felt that painting should not be considered photographic, and he probably abhorred the title photorealist sometimes appended to his name. Continuing on this point Sheeler once said "[p]hotography is only visual, thank God! The lens is an unpsychological piece of glass [.]" (Wight, 1954, p. 26). Although his desire to be a painter always outweighed that toward photography, it was not until the beginning of the 1930s that he abandoned his job as a commercial photographer. In his 1932 article on Sheeler, Ernest Brace comments:

Sheeler was a painter first, turning to photography as a pleasant and interesting way to earn his living. That he mastered the craft so completely is characteristic of the man. A glance at any of his paintings is sufficient to prove him the sort of person who would do nothing without a thorough understanding and rigid mastery of his materials, and it is his meticulous care with every square inch of his drawings and paintings that leads the casual observer to label his work photographic and therefore mechanical and to conclude further that it was his work in photography which determined his art. It is rather his art and his attitude toward art which have determined his photography. (Brace, 1932, p. 100)

From 1926 to 1929 Sheeler's painting output declined precipitously, while his reputation as a photographer grew dramatically, particularly through his commissioned images of the Ford Motor Company's River Rouge Plant, executed during late 1927 and early 1928.

In 1929, Sheeler painted the image Upper Deck, which he later said brought everything together for him as a painter. Shortly after executing this image, he was finally able to partially abandon his career as a commercial photographer and dedicate more time to his painting. He stated that Upper Deck altered his conception of what a picture should be:

With this painting it became my custom to build up gradually a mental image of the picture before the actual work of putting it down began. Something seen which keeps reoccurring in one’s memory, with insistence increasingly vivid, and with attributes added which had escaped observation on first acquaintance. In the course of time the accumulation takes on a personal identity and the picture attains a mental existence complete within the limits of one's potentiality. Since the value of the mental picture can only be determined by the degree of response it is able to arouse in another person, it must be restated in physical terms- - hence the painting. ${ }^{9}$

This evaluation of his new painting process reveals how far Sheeler had evolved since his training with William Merritt Chase. It also reveals his application of the concept of the painting as a composite image. This marked change in process represented Sheeler's realization that this "mental image" of the subject matter must hold within it an accumulation of experience, and that this experience is recalled in the painting through the

\footnotetext{
${ }^{8}$ See Charles Sheeler Papers, “Autobiography”, p. 77.

9 See Charles Sheeler Papers, p. 83.
} 
artist's memory of specific, vivid elements. By using memory, as opposed to simple, immediate reaction, and taking sometimes as much as nine months to finish one work, Sheeler found the formal process that could convey his understanding of the local, as seen through Williams' writing. This also solidified his concept of the painting as above the photograph.

When discussing Upper Deck, Sheeler stresses the personal contribution of the artist to his subject matter, and the need for this period of reflection upon the lived experience, in order to bring it to life in the artistic present. In Sheeler's note to a 1939 exhibition of his work at the Museum of Modern Art, he singles out this canvas:

The painting Upper Deck of 1929 marks the dividing line between my previous work and that which has followed in regard to my approach to a picture, which continues to prevail. Starting with Upper Deck I have sought to have a complete conception of the picture established in my mind, much as the architect completes his plans before the work of bringing the house into existence begins. ${ }^{10}$

It was this view of the self-expression capable through creation based on an aesthetic of place that cemented Sheeler's conception of Williams' application of the local. This understanding of the creation of a local aesthetic had been further revealed to Sheeler via In the American Grain four years earlier. With Upper Deck Sheeler finally found the formal expression he was heading towards in Staircase, Doylestown (1925), painted the same year In the American Grain was published. Like Williams, Sheeler found the answer to his expressive aims through a return to a more highly objective rendering of his local subject matter. Sheeler, essentially, appropriated the image for Upper Deck, in the same fashion that Williams appropriates history in In the American Grain. Considering the theme of Upper Deck, Rourke mentions that Sheeler said it "involved no arbitrary rearrangement because of an aesthetic impulse." Sheeler elaborates that the "forms existed on their own terms, for use" and that they became beautiful through their "function" as a painted image. ${ }^{11}$

Upper Deck has been noted by many critics and scholars as the turning point in Sheeler's painting career, as it was the one work which he referred to at length within his brief, extant writing. Frederick Wight makes special note of the painting in his essay for Sheeler's retrospective in 1954. He stops himself mid-essay, as if just realizing this important misstep in his analysis of Sheeler's career as a painter:

But we are passing over a landmark in going from the stimulus to the date when the paintings emerged with a life of their own. In 1929 Sheeler painted Upper Deck, a key canvas. The subject is perfect for his purpose. Marine architecture is dynamic by the nature of the sea that molds it; drive and flow create tensions between the straight line and the curve, and there is tension too between the crowded space and the sparse forms. There is a further tension in the repetition, the fugue in the composition, for there are two dynamos, two vents and two blowers whose intakes are competitive blacks, two deadeyes: "Black and I mean black, like pistol shots." There were some preliminary studies, but this was the first painting foreseen in the clear, complete in the artist's mind before it was begun. (Wight, 1954, p. 28)

Wight quotes Sheeler here by pointing out the vivid, reoccurring memory the artist had after his time photographing the ship, "black, like pistol shots". Nevertheless, the subject matter of the grand machine again is brought to the artist not by his own free will but by a specific commission. While formally Upper Deck achieves the kind of expression that will be seen henceforth in his painting, the subject matter is atypical in comparison to Sheeler's common preferences. Sheeler abhorred his day job as a commercial photographer. He stated of his time as a photographer at Condé Nast, "I didn’t have to wash my mouth with antiseptic" (Wight,

\footnotetext{
${ }^{10}$ See Charles Sheeler, “A Brief Note on the Exhibition”, pp. 10-11.

11 See Charles Sheeler quoted in Rourke, p. 145.
} 
1954, p. 28). Therefore, the use of a commissioned photograph for a painting speaks to one sense of the local that Williams had instilled within Sheeler, the use of image appropriation for the purpose of revealing a local aesthetic through personal reflection.

\section{Conclusion}

In a letter from Williams to Sheeler dated October 30, 1958, the writer responds to the painter's praise with the following:

I'm not your master, far from it—-though if you want to call me so for some obscure reason I can only say-Nuts to you! - with full respect and love. Sometimes it comes over me with devastating force how far I AM FROM mastery, which is a spiritual quality in what I do. That's no reason to despair. We do what we can to come out of ourselves so that through the paint or words the thing behind them will most show. ${ }^{12}$

For both it was an immediate contact with the object that always inspired their formal ideas, and, more specifically, it was the day-to-day living with that object that more clearly revealed the dialogue of the local. Williams is obviously responding to the importance Sheeler placed upon the writer's artistic influence. It appears that Sheeler was quite comfortable with giving Williams credit for the immense influence the poet had upon his manipulation of form and content within his painting. This note sums up their shared desire for personal expression through the local-ideas expressed through things. The decade of the 1920s was pivotal to Sheeler's shaping of a paragone within his chosen media. From 1923 to 1929 Williams would relay to Sheeler his full program for the creation of a local aesthetic. This cross-fertilization of ideas would culminate in Sheeler's view that the local could be expressed only through the painting. In this aesthetic sense, the photograph retains its status as "single image", as it cannot compete with the expressive capabilities of the multi-faceted, painted form, or "composite image”. Sheeler's work within a variety of media drove him to consistently question the expressive capabilities of each. This work in between materials and processes, coupled with the literary influence of Williams, would inalterably shape his concept of a hierarchy of media.

\section{References}

Brace, E. (1932, October). Charles Sheeler. Creative Art, 1 (2), 97-104.

Charles Sheeler Papers, Archives of American Art, Smithsonian Institution, Washington, D.C.

Charles Sheeler Papers, Arensberg Archives, Twentieth Century Department, Philadelphia Museum of Art.

Dewey, J. (1920, January to June). Americanism and localism. The Dial, (68), 684-688.

Diggory, T. (1991). William Carlos Williams and the ethics of painting. Princeton: Princeton University Press.

Dijkstra, B. (1969). Cubism, Stieglitz, and the early poetry of William Carlos Williams. Princeton: Princeton University Press.

Dijkstra, B. (Ed.). (1978). A recognizable image: Williams Carlos Williams on art and artists. New York: New Directions.

Halter, P. (1994). The revolution in the visual arts and the poetry of William Carlos Williams. Cambridge: Cambridge University Press.

Horak, J. (1995). Paul Strand and Charles Sheeler's Manhatta. In J. Horak (Ed.), Lovers of cinema: The first American film avant-garde 1919-1945. Madison: University of Wisconsin Press.

Lucic, K. (1997). Charles Sheeler in Doyslestown: American modernism and the Pennsylvania tradition. Allentown: Allentown Art Museum.

Marling, W. (1982). William Carlos Williams and the painters 1909-1923. Athens: Ohio University Press.

Rourke, C. (1938). Charles Sheeler: Artist in the American tradition. New York: Harcourt, Brace and Company.

Sayre, H. (1983). The visual text of William Carlos Williams. Urbana: University of Illinois Press.

\footnotetext{
${ }^{12}$ Williams, “Letter to Charles Sheeler, dated October 30, 1958,” Charles Sheeler Papers, (Washington D.C.: Smithsonian Institution Archives of American Art).
} 
Schmidt, P. (1988). William Carlos Williams, the arts, and literary tradition. Baton Rouge: Louisiana State University Press.

Sheeler C. (1939). A brief note on the exhibition. In Three painters of America: Charles Demuth, Charles Sheeler, Edward Hopper. New York: The Museum of Modern Art.

Stewart, R. (1983, November). Charles Sheeler, Williams Carlos Williams, and precisionism: A redefinition. Arts Magazine, 58(3), 100-114.

Tashjian, D. (1978). William Carlos Williams and the American scene 1920-1940. New York: Whitney Museum of American Art. Wight, F. (1954). Charles Sheeler: A retrospective exhibition. Los Angeles: University of California Art Galleries.

Williams, W. (1939a). A brief note on the exhibition. In Three painters of America: Charles Demuth, Charles Sheeler, Edward Hopper. New York: The Museum of Modern Art.

Williams, W. (1939b). “Introduction” to “Charles Sheeler: Paintings, drawings, photographs”. In Three painters of America: Charles Demuth, Charles Sheeler, Edward Hopper. New York: The Museum of Modern Art.

Williams, W., \& McAlmon, R. (Eds.). (1920, December). Call for entries. Contact, 10. 